\title{
The Language of Seafaring: Standardized Conventions and Discursive Features in Speech Communications
}

\author{
ANA BOCANEGRA-VALLE* \\ Universidad de Cádiz
}

Received: 30 January 2010 / Accepted: 24 March 2010

\begin{abstract}
This paper portrays how English language is constructed and displayed by shipboard crews and shore-based personnel when communicating through radiotelephony. Based on internationally-recognized recommendations for implementation when ships communicate with each other or with shore-based stations as well as on examples of current practice contained in marine communication manuals, this paper explores the message patterns, the standardized conventions, and the general and discursive practices governing speech communications at sea. Firstly, marine communications are defined and the role of Maritime English in the shipping industry for ensuring a safe and efficient passage discussed. Then, the standardized language of the sea is explained. Next, a move-step model to the analysis of the stages making up communicative exchanges at sea is applied and the main general and discursive features that prevail in such exchanges described. Finally, two examples help to illustrate the model and features presented and discussed.
\end{abstract}

\section{KEYWORDS:}

Marine communications, maritime English, oral discourse, specialized discourse, move-step model, discursive features, standard marine communication phrases.

\section{RESUMEN}

El presente trabajo aborda el uso de la lengua inglesa por parte de los buques y el personal marítimo de tierra al comunicarse a través de radiotelefonía. Partiendo de recomendaciones internacionales de obligado cumplimiento así como de ejemplos prácticos recogidos en los manuales de comunicaciones marítimas, examinamos los modelos de mensaje, las convenciones normalizadas y las fórmulas discursivas generales y específicas por las que se rigen las comunicaciones orales en el ámbito marítimo. En primer lugar se definen las comunicaciones marítimas y se estudia el papel que juega la lengua inglesa en la navegación. Seguidamente se describe el lenguaje normalizado del mar. A continuación, y mediante un modelo de movimientos y pasos se analizan las fases que conforman un evento comunicativo marítimo y se describen las características generales y discursivas principales que predominan en dichos eventos. Por último, se incluyen dos ejemplos con el fin de ilustrar el lenguaje normalizado, las características discursivas y el modelo estudiados.

\section{PALABRAS CLAVE:}

Comunicaciones marítimas, inglés marítimo, discurso oral, discurso especializado, modelo de movimientos y pasos, características discursivas, frases normalizadas para las comunicaciones marítimas.

*Address for correspondence: Ana Bocanegra-Valle. Dpto. de Filología Francesa e Inglesa, Facultad de Ciencias Náuticas, Campus Universitario 11510, Puerto Real, Cádiz, Spain. Tel: 0034 956016122; 63185; Email: ana.bocanegra@uca.es 


\section{INTRODUCTION}

Marine communications have developed quickly since Morse Code was first used aboard ships by the end of the nineteenth century. In the 1930s ships began to be fitted with radiotelephone capabilities, and, although still limited, verbal or speech communications became possible on the high seas. More recently, satellites have paved the way to more sophisticated, more reliable and more varied means of communication that have little to do with the visual and audible signals used by seafarers in former times. Today, radiotelephony or communication by means of Very High Frequency (VHF) radio - remains the most common option when communicating through speech with other ships and with shore-based facilities with a variety of purposes and within a range of 40 to 2000 miles. In particular, VHF transceivers assist in effective communication between short distances and are the most common devices when transmitting and receiving information to and from ships or shore stations both in territorial waters and inland waterways.

In marine radio communications the English language as a common language of international use is at the forefront. In fact, "thousands of crew on board today's merchant ships receive intensive training in Maritime English communication before going to sea" (Short, 2006: 2), because it is not only important that English language be used appropriately, but also that messages be transmitted correctly; that is, observing standard procedures, applying message patterns and making use of the expected discursive features.

This paper is intended to provide an overview of how English discourse is constructed in verbal marine communications as recommended by the International Maritime Organisation (IMO) and contained in maritime communications manuals. To achieve this general aim, a move-step model for the analysis of message patterns has been adopted and applied. Also, the discursive features, the communication conventions and the official recommendations which must be observed by seafarers when communicating internationally by VHF radio are explained and illustrated. Likewise, other key questions are addressed namely, the English language as an international language for communicating at sea, minimizing the risk of shipping accidents and ensuring safer ships; and the origins and development of the standardized language of the sea with particular reference to the work undertaken by IMO. Finally, examples of seaborne communicative events that help to illustrate the move-step model, the discursive elements and the communicative conventions detailed are also included and discussed.

\section{THE ROLE OF MARITIME ENGLISH}

In the following subsections I will try to (1) explain what verbal marine radio communications are and how they can be classified; (2) raise awareness on the importance of Maritime English to the shipping industry and safety at sea; and (3) sump up IMO's effort in 
promoting the English language as the international language of the sea through the development of the Standard Marine Communication Phrases.

\subsection{Maritime English and speech communications}

At present, the English language is recognised worldwide as the international language to be used at sea because "communication in English takes place incessantly in all ports, straits, fairways, waterways, or sea routes of the world between and among speakers who are almost ninety-percent non-native speakers of English" (Pritchard, 2003a: 153). Organisations such as the International Maritime Organisation (IMO), the International Telecommunications Union (ITU) or the International Association of Lighthouse Authorities (IALA) have established resolutions, recommendations, rules and procedures that have contributed to enhance the English language as the common language of seafaring around the world and harmonize language forms and procedures ${ }^{1}$.

Maritime English has grown in importance and gained widespread use given the challenges of today's global trade (Bocanegra-Valle, 2010). Pritchard and Kalogjera (2000: 185) define Maritime English for VHF communication purposes (or English for maritime communications) as "a specific, narrow-scope realisation of Maritime English", a highly restricted sub-variety of maritime English characterised by "a limited vocabulary and simple grammatical structure to suit the specific requirements of interpersonal communication and interaction".

Verbal, voice or speech marine communications mainly embrace face-to-face conversations, VHF radiotelephony, or broadcasting services, and may occur: (i) when shipboard crews communicate face to face with professional purposes, through the use of walky-talkies or by means of the ship's internal communication systems (this is known as internal, intra-ship, or on-board communication); or (ii) when shipboard crews and shorebased personnel communicate with each other, with other vessels, with aircraft or with shorebased services (this is known as external, inter-ship, or ship-to-shore/shore-to-ship communication). In this particular case, radiotelephony is the most frequent.

VHF radio communication (or radiotelephony) is the most important means of day-today seaborne communication, particularly in the case of ship-to-shore/shore-to-ship communication. When communicating orally at sea, information exchanges and broadcasts must be as clear, concise and precise as possible. VHF-transmitted information must be free from ambiguity, brief, relevant and meaningful while also being systematically delivered and still achieving its communicative purpose. It is not simply a question of good English but of adherence to internationally agreed standard phrases and discursive practices and conventions.

The main features of marine communications have been thoroughly explained and illustrated in both scholarly papers (De la Campa, 2007; Díaz Pérez, 2002 \& 2005; Johnson, 1995 \& 1999; Olaru, 1996; Pritchard \& Kalogjera, 2000), reports (Pritchard, 2003b), and 
textbooks (Blakey, 1987; Pritchard, 1999; Van Kluijven, 2003; Weeks, 1986; Weeks et al., $1988)^{2}$.

\subsection{Maritime English and ship safety}

Following abundant research conducted by specialised agencies around the world such as the European Maritime Safety Agency (EMSA) with its headquarters in Lisbon (Portugal), the Marine Accident Investigation Branch (MAIB) in the UK, the National Transportation Safety Board (NTSB) in USA or the Canadian Transportation Accident Investigation and Safety Board, to name a few, there have been many shipping accidents in which language misunderstandings when speaking through VHF radio have been found to be the main cause or a contributory factor to the accident. Hence, the efficient use of the English language at sea (Maritime English) is a key factor in ensuring safe ships, clean oceans and successful business operations because "problems of communication may cause misunderstandings leading to dangers to the vessel, the people on board and the environment" (IMO, 2001: 3); more particularly, "navigational and safety communications from ship to shore and vice versa, from ship to ship, and on board ship must be precise, simple and unambiguous so as to avoid confusion and error" (IMO, 2001: 3). Also, lessons learned after a shipping accident often emphasize that "clarity of language is everything at sea. VTS operators, pilots and masters must ensure there can be no ambiguity at all in what they say over the radio" (MAIB, 2000: 14).

The absent, poor or careless use of basic Maritime English for communication purposes accounts for around 20\% (De la Campa, 2003) or even 30-40\% (Trenkner, 2000) of shipping accidents resulting in emergency situations, harm to the marine environment and loss of human life $^{3}$. As I argued elsewhere, "Poor language abilities contribute to unsafe acts by seafarers, violations of good practice and established rules, work underperformance and, consequently, to carelessness and confusion which may embody tragic results. The consequences of such inadequate English language knowledge and skills may range from mere annoyance to normal operations to all sorts of occupational accidents, personal injury, death, cargo loss, damage to property or irreversible environmental impact" (BocanegraValle, 2010: 158).

Lastly, a proficient use of Maritime English is particularly important in the case of multilingual and multicultural (multi-ethnic or mixed) crews as English will be the common language for communication not only with professional but also with personal purposes. It has been estimated that almost $90 \%$ of crews having English as their working language are not native speakers of English (Johnson, 1999; Pritchard, 2003a), that more than nine out of ten shipping industry professionals are non-native speakers of English (Trenkner, 2000) and that over $60 \%$ (Kahveci \& Sampson, 2001) of the world's fleet are manned and operate with mixed crews so that even a dozen (or even more) different nationalities with a dozen different 
languages may be together aboard ship or at a shore-based station (Kahveci \& Sampson, 2001; Short, 2006).

\subsection{The standardized language of marine communications}

The standardized language of marine communications for inter-ship and intra-ship use is contained in the Standard Marine Communication Phrases (SMCP) (IMO, 2001). The SMCP (commonly referred to as the standard phrases) is the revised, updated and enhanced version of the Standard Marine Navigational Vocabulary (SMNV), and was developed after a fire devastated the Scandinavian Star ferry with the loss of 158 human lives. The former SMNV (adopted in 1977, and further revised and amended in 1983 and 1985) was the first official step undertaken ${ }^{4}$ towards the recognition of English as "a common language for international communications between ships and between ships and shore services" (IMO, 1977). The SMCP was developed by the Sub-Committee on Safety of Navigation as instructed by the Maritime Safety Committee, and was finally adopted on 29 November 2001 by IMO's General Assembly under its agenda item 9.

The standard phrases, divided into parts and chapters, were set out in Annex 1 of Resolution A.918(22) after recognizing the wide use of the English language for international navigational communications and recalling that "English shall be used on the bridge as the working language for bridge-to-bridge and bridge-to-shore safety communications as well as for communications on board between the pilot and bridge watchkeeping personnel unless those directly involved in the communications speak a common language other than English" (IMO, 2001: 1).

As IMO explains in the introduction to the SMCP, such phrases were compiled with the aim of assisting in the greater safety and conduction of a ship, and also of standardizing the oral language used in communications at sea, in harbours and waterways and on board. Peter Trenkner, head of the Working Group at IMO responsible for the development of the SMCP, recalls that his Group was required, among others, to reduce "the grammatical and idiomatic diversity of Maritime English to strictly purposive" and also "the terminological diversity of Maritime English to a basic terminology” (Trenkner, 2005: 10).

The target group of SMCP users are any crew member and shore-based personnel with radio communication responsibilities, regardless their fluency in General English. This is, both non-native speakers and near-native or native speakers must adhere to the SMCP; the former are required to use standard Maritime English fluently and the latter to adapt their everyday use of the language to the knowledge of potential interlocutors.

From the time the SMNV was in force until very recently, different authors have complained about the little use of these phrases in real-life situations and claim further investigation into this particular issue (De la Campa, 2007; De la Campa et al., 2007; Díaz Pérez, 2002 \& 2005; Johnson, 1995 \& 1999; Olaru, 1996; Pritchard, 2000, 2003a \& 2003b; 
Pritchard \& Kalogjera, 2000; Squire, 2006; Trenkner, 2005) at the same time they urge shipping companies and ship owners, rather than training institutions, to bind their crew to such standardized language and procedures. Works like those by De la Campa et al. (2007) or Pritchard and Kalogjera (2000), based on corpora of authentic VHF communications recordings, evidence a wide gap between the formal requirements of standardized VHF verbal communications and everyday English as used in real maritime situations. These two works provide some examples of non-compliance and deviations from IMO's standard phrases and procedures.

Indeed, to what extent and how standardized radio communication, that is, IMO's standard phrases, deviates from real use is an area that should be researched in depth. Seafaring is a complex activity involving extrinsic and intrinsic (human) factors, Maritime English being part of the latter ${ }^{5}$. Hence, strict adherence to standardized VHF procedures, proper training of seafarers in the "art of effective communication" (Squire, 2006: 25) and fluent English speakers both on board and ashore can assist in reducing the estimated $20 \%$ of shipping accidents due to language communication problems.

\section{SPEECH COMMUNICATIONS AT SEA}

In the following subsections I will try to (1) explain the internationally agreed patterns, conventions and procedures regarding the use of the standardized English language that seafarers use when transmitting and receiving information via radiotelephony; (2) describe the main discursive features that characterise standardized messages; and (3) illustrate how such conventions and features are put into practice for efficient communication at sea on the basis of the preceding discussion.

\subsection{Standardized verbal message patterns}

Broadly speaking, there are two main patterns of radiotelephony calls or messages to be delivered from a transmitting or calling station (vessel or shore-based station) to a receiving station (vessel or shore-based station): special-purpose messages and routine messages. These may be respectively subdivided into three and eight message types, and are initiated by particular message markers as detailed below.

1) Special-purpose messages. These involve distress, urgency and safety calls with the following peculiarities:

1.1) Distress messages: they announce an imminent danger to a ship likely to involve loss of life and requesting immediate assistance. Distress calls are preceded by the word Mayday (from the French m'aidez) repeated three times, and transmitted on Channel 16 of the VHF set. 
1.2) Urgency messages: they indicate that the information following must be immediately known by ships in the vicinity as it contains urgent information concerning the safety of a ship or a person. These are preceded by the word Pan$P a n$ repeated three times.

1.3) Safety messages: they indicate that the information following covers important navigational or meteorological warnings of interest to nearby ships and traffic services, and are preceded by the word Sécurité repeated three times.

2) Routine messages. These refer to calls intended to ensure a safe passage. Any piece of information different from the three above will be regarded as within the scope of a routine message. Routine messages may be divided into eight types and each of these is preceded by that very same message marker -for example, a request message will begin with the word Request. Details, as they appear in IMO (2001: 47-48), are the following:

2.1) Instruction: message implies the intention of the sender to influence others by a Regulation.

2.2) Advice: message implies the intention of the sender to influence others by a Recommendation.

2.3) Warning: message implies the intention of the sender to inform others about danger.

2.4) Information: message is restricted to observed facts, situations, etc.

2.5) Question: message is of an interrogative character.

2.6) Answer: message is the reply to a previous question.

2.7.) Request: message asks for action from others with respect to the vessel.

2.8) Intention: message informs others about immediate navigational action intended to be taken.

Once a routine message has been received, the receiving station will repeat the message marker followed by received and the corresponding action. For example, Request received, Information received, and so on.

Message markers fulfil an informative function in the sense of minimising assumptions and anticipating the speaker's communicative intention as well as reducing the level of unexpectedness on the hearer's part. They also help to eliminate misunderstandings that may arise from the wrongful interpretation of intonation patterns and hence assist in the final understanding of the information delivered. The inability to perceive intonation patterns is an important problem inherent to marine radio communications given the high noise levels aboard ships and the very technical nature of VHF transceivers (prone to interferences or transmission gaps) through which voice is transmitted and received. Table 1 contains examples of phrases for these message patterns and types as extracted from IMO's SMCP: 


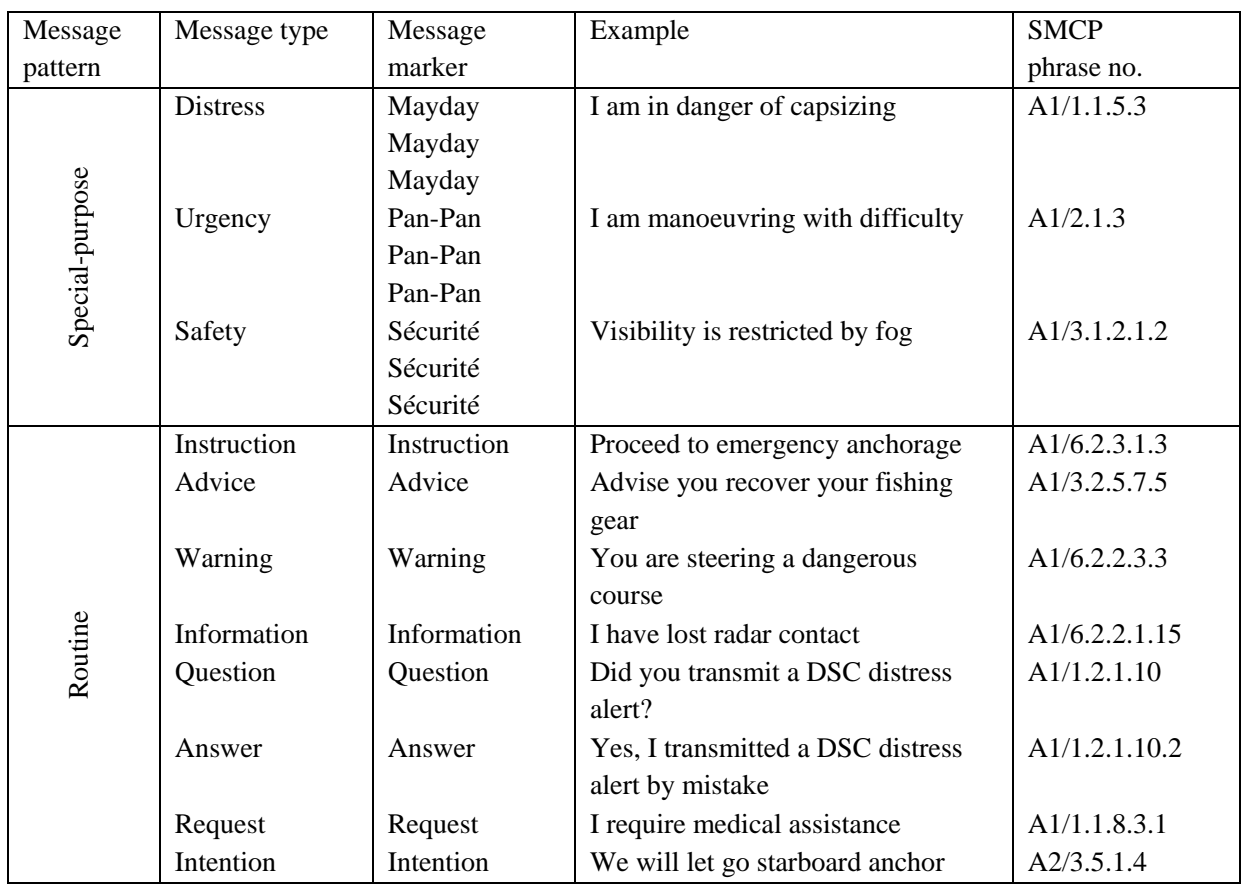

Table 1. Examples of SMCP phrases as classified by message patterns and types.

\subsection{Move analysis applied to standardized verbal messages}

VHF conversations follow a particular structure of communicative stages and information requirements that are observed worldwide. Following Swales's (1981) terminology for the description of the rhetorical structure of research article introductions, I will argue that VHF messages may be structured into three main moves and subsequent steps. These are shown in Tables 2 and 3, and discussed in the following paragraphs for special-purpose (Table 2) and routine (Table 3 ) calls.

Special-purpose messages are made up of three moves and eight steps in all (see Table 2). Special-purpose messages differ from routine messages in that, at least in a first stage, there is no communicative exchange taking place but a need, often urgent, to send a message reporting a distress alert (distress call), a severe injury (urgent call), or an important navigational issue (safety call). Once the major information has been transmitted, the receiving station may contact the calling station back so as to clarify information or gather more relevant data about the safety issue, urgency or imminent danger reported (collision, fire, flooding, grounding, etc.) and initiate search and rescue operations as required. 


\begin{tabular}{|l|l|}
\hline Moves & Steps \\
\hline \multirow{5}{*}{ 1. Initiate message } & 1.1. Indicate message marker \\
\cline { 2 - 2 } & 1.2. State addressee (receiving station/all ships) \\
\cline { 2 - 2 } & 1.3. Identify oneself (calling station) \\
\cline { 2 - 2 } & 1.4. Indicate ship's position \\
\hline \multirow{2}{*}{$\begin{array}{l}\text { 2. Send message / } \\
\text { Broadcast information }\end{array}$} & 2.1. State nature of distress, imminent risk or relevant data \\
\cline { 2 - 2 } & 2.2. State assistance required \\
\cline { 2 - 2 } & 2.3. State addition information or important requirements \\
\hline 3. End of message & 3.1. Switch off/Indicate end of message \\
\hline
\end{tabular}

Table 2. Moves and steps making up the general structure of special-purpose messages.

Move 1 Initiate message requires a ship to transmit the corresponding message marker (Mayday, Sécurité or Pan Pan, depending on the nature of the message) (step 1.1.) and address a particular receiving station, if known, or all ships so as to oblige any ship in the area to take appropriate actions (step 1.2.). The ship (calling station) will identify herself by stating her name and call sign (step 1.3.) and indicating her position (step 1.4.). As a difference to routine messages, if a ship is equipped with digital selective call (DSC) equipment, Move 1 will not be verbally achieved but computer generated and automatically delivered. This is, a call may be digitally announced (hence, initiated) by DSC and, immediately after this, spoken communication will continue on $\mathrm{VHF}^{6}$.

Once a message has been initiated, Move 2 Send message / Broadcast information applies. The ship will transmit the information of concern in a concise but, at the same time, informative manner (step 2.1.); if it is the case, she will ask for the necessary assistance given the nature of the distress or urgency (step 2.2.) and will state any additional information of particular relevance to the situation (step 2.3.).

Finally, Move 3 End of message will serve to finish the message and bring the communicative event to an end (step 3.1.). As the situation develops, a ship or station receiving the data may wish to contact the calling station (in this case, a ship) back for further information or to report the actions taken or to be taken. In this case, a message exchange procedure would apply (see Moves 2 and 3 for routine messages in Table 3). Routine messages are made up of three moves as well and a maximum of sixteen steps (see Table 3 ).

Move 1 Initiate conversation / Establish contact is the first action taken by a ship or shore-based station wishing to send a message and all steps will be repeated by the receiving station until the medium of communication (VHF channel) has been agreed upon. In the first place, the calling station (let's say a ship) will address another ship or shore-based station with a particular purpose in mind. In so doing, this calling ship will state the addressee's name (step 1.1.) in the first place. Then, the ship will identify herself by means of name followed by call sign (step 1.2.). In the subsequent step, the ship will indicate the VHF channel that will be used for the communicative exchange (step 1.3.) and will put an end to this conversation turn (step 1.4.). If the receiving station finds such VHF channel suitable for the message exchange to run smoothly, it will confirm (agree) that channel or either reject it (due to poor sound 
quality or distortions) and, hence, suggest an alternative one (step 1.3.). In this latter case, speakers would run through steps 1.1. to 1.3. until they agree on the most suitable working channel.

\begin{tabular}{|c|c|c|}
\hline Moves & \multicolumn{2}{|l|}{ Steps } \\
\hline 1. Initiate & \multicolumn{2}{|l|}{ 1.1. State addressee (receiving station) } \\
\hline conversation / & \multicolumn{2}{|l|}{ 1.2. Identify oneself (calling station) } \\
\hline Establish contact & \multicolumn{2}{|c|}{ 1.3. Indicate VHF working channel / Agree or disagree working channel } \\
\hline & \multicolumn{2}{|l|}{ 1.4. Switch over/indicate end of turn } \\
\hline \multirow{7}{*}{$\begin{array}{l}\text { 2. Send message } \\
\text { / Exchange } \\
\text { information }\end{array}$} & Stage a: Initial stage & Stage b: Subsequent stages \\
\hline & 2.1.a Address receiving station & 2.1.b Address receiving station \\
\hline & 2.2.a Identify calling station & 2.2.b Identify calling station \\
\hline & 2.3.a Indicate ship's position & \multirow{2}{*}{$\begin{array}{l}\text { 2.3.b Exchange messages information as } \\
\text { appropriate }\end{array}$} \\
\hline & 2.4.a Indicate time of transmission & \\
\hline & 2.5.a State nature of communication & \multirow[t]{2}{*}{ 2.4.b Switch over/indicate end of turn } \\
\hline & 2.6.a Switch over & \\
\hline \multirow{6}{*}{$\begin{array}{l}\text { 3. End of } \\
\text { conversation }\end{array}$} & \multicolumn{2}{|l|}{ 3.1. Address receiving station } \\
\hline & \multicolumn{2}{|l|}{ 3.2. Identify calling station } \\
\hline & \multicolumn{2}{|l|}{ 3.3. Acknowledge final message } \\
\hline & \multicolumn{2}{|l|}{ 3.4. Bid farewell and thank politely } \\
\hline & \multicolumn{2}{|l|}{ 3.5. State intention to end call } \\
\hline & \multicolumn{2}{|l|}{ 3.6. Switch off/Indicate end of message } \\
\hline
\end{tabular}

Table 3. Moves and steps making up the general structure of routine messages.

Move 2 Send message / Exchange information involves the communicative exchange properly speaking and will be cyclically applied, that is, the steps will be repeated by addressing and addressed stations along with the conversation until the call is about to come to an end. Move 2 will begin as soon as Move 1 has been completed successfully and the contact has been acknowledged by both stations. Steps vary depending on a first contact (Stage A) or subsequent contacts (Stage B). In this case, the ship will name the addressee (receiving station) once again (step 2.1.a.); next, she will identify herself (step 2.2.a.), she will indicate her position (step 2.3.a.) and will notify the exact time of the transmission taking place (step 2.4.a.). Finally, the communicative exchange will be developed between the speakers involved who will be alternatively be acting as calling or receiving stations (steps 2.5.a. and 2.6.a. into steps 2.1.b. to 2.4.b.). Here, message markers (see Table 1) will signal the aims of the message and govern the communicative exchange.

Move 3 End of conversation serves the purpose of completing the conversation. The two first steps are similar to those for Moves 1 and 2 (steps 3.1. and 3.2.). Next, the caller confirms the last piece of information received (step 3.3.), thanks and say goodbye politely (step 3.4.), shows intention to finish the message (step 3.5.), and switches the VHF set off (step 3.6.).

Each of these steps make use of discursive features (both general and specific) which strengthen the standardized communicative procedure and the standardized message patterns 
governing the final purpose of verbal communications at sea. Such general and specific features are discussed and illustrated in the following subsections.

\subsection{Discursive features of standardized verbal communications}

Standardized verbal marine communications are depicted as a formal, or even highly formal, register, especially if they concern safety of navigation (Pritchard, 2003a). Standardized messages and phrases show both general and specific discursive features characterized by the use of particular terminology and instances of language use in view of reducing the time of verbal communications and constructing short, clear and precise messages just focused on particular events or relevant information to the seafaring episode.

The general discursive features of standardized verbal messages refer to general rules that have governed the compilation of standard phrases (SMCP) and that are expected to be applied to verbal marine transmissions under IMO's recommendations. These are the following (IMO, 2001) ${ }^{7}$ :

1) Avoidance of synonyms: Words will be used consistently throughout so that, for instance, vessel has been agreed to be used instead of ship to refer to the ship herself. Example: "No vessel in vicinity" (B2/6.2.8.1) will be the correct phrase to be transmitted when communicating that there are no other ships around.

2) Avoidance of contracted forms: Auxiliary verbs and not-forms will not be contracted in view of pronunciation clarity. Example: "I cannot locate you on my radar screen" (A1/6.2.2.1.8).

3) Provision of fully worded answers to yes/no-questions: Replies will not be restricted to a simple "yes" or "no" but fully developed containing all the question items. Example: there will only be two answers to the question "Is the turning effect of the propeller very strong" (A2/3.2.5), which are "Yes, the turning effect of the propeller is very strong" (A2/3.2.5.1) or "No, the turning effect of the propeller is not very strong" (A2/3.2.5.2).

4) Provision of fully worded responses to instructions, pieces of advice, or orders: Messages will be acknowledged at all times. If, in particular, an instruction, an order or a piece of advice is transmitted, the receiving station will make sure that the information has been received and understood by repeating the main wording preceded by I will/can or I will not/cannot. Example: "Stop engines until pilot boat is clear" (A1/4.2.18) will be expected to get the following reply: "I will stop engines until pilot boat is clear".

5) Provision of basic alternative answers to sentence questions: One question is likely to obtain several replies, and these are listed as appropriate and preceded by tildes ${ }^{8}$. Example: Alternative answers to the question "What is wrong with the pilot ladder?" 
(A1/4.2.6) are these six: "The pilot ladder $\sim$ has broken / loose steps. $\sim$ has broken spreaders. $\sim$ has spreaders too short. $\sim$ is too far aft / forward." (A1/4.2.6.1).

6) Structuring of phrases according to the principle "identical invariable plus variable": This means that one sentence may be completed with alternative statements so as to extend the basic information provided initially. Example: "I expect to refloat $\sim$ at $\ldots$ hours UTC $\sim$ when tide rises $\sim$ when weather improves $\sim$ when draft decreases $\sim$ with tug assistance ..." (A1/1.1.4.7.1)

7) Provision of a single phrase for a single event: One event will be identified by one sentence so that phrases are straightforward and information is as simple and precise as possible. Example: to indicate the need to continue the search operation and know more about the incident the transmission will be "Continue search in position ... Try to obtain information from survivors" (A1/1.2.4.3 and A1/1.2.4.9); this is, two sentences for two events.

8) Preference of Latinisms over other options: Sentences containing verbs such as continue, abandon, require, proceed or nouns such as assistance or persons are preferred over go on, leave, need, sail, help or people, respectively. Example: "I can proceed without assistance" (A1/1.1.2.7) in lieu of "I can sail without help", or a similar alternative.

9) Flexible application of a block language: This means little use of function words if this does not affect communication negatively. Example: "Danger of icing in area around ..." (A1/3.1.3.6) will be used to notify that "there is a danger of icing in the area around ...".

Specific discursive features refer to the way language is used to apply standardized communicative procedures and, as such, they may be understood as an organisational language shaping verbal discourse and aiming at optimal communicative performance. Specific discursive features are mainly organisational terminology and phrases used with particular purposes as summarized below.

10) Strict application of message markers: Routine and special-purpose messages will be preceded by the corresponding message markers (see Table 1).

11) To indicate one's intention to use the SMCP, or ask the calling station to do so, the two sentences to be used will be: "Please use IMO Standard Marine Communication Phrases" and "I will use IMO Standard Marine Communication Phrases".

12) The end of a transmitted piece of information will be indicated with the use of the word Over, whereas Out will be used to indicate that the whole information exchange has been completed.

13) If a speaker wishes to thank the hearer and put an end to the message, common phrases will be "Thank you", "Nothing more", "Have a good watch", or "Have a pleasant voyage". 
14) Letters and numbers will be spelt following the Phonetic Alphabet so that, for instance, letter $A$ will be spelt as Alfa. Numbers will be spoken digit by digit (except for wheel orders) so that 180 will stand for one, eight, zero -the Figure Code may also be used to spell numbers, if appropriate. ${ }^{9}$

15) Ships and shore-based stations will be addressed by just verbalizing their names (repeated three times at least in the first stages of the exchange, that is, Move 1). In case of no particular addressee, the phrase "All stations" or "All ships" will be used as appropriate.

16) Ships and shore-based stations will identify themselves by stating their names and MMSI code and/or call signs ${ }^{10}$. In both cases, data will follow the phrase "This is ...". For example, "This is two-one-one-two-three-zero-zero-eight-six motor vessel Erika call sign Delta Kilo Papa Oscar".

17) When a piece of information is not immediately available, "Stand by" will be used; and when a piece of information cannot be obtained, "No information" will be the correct reply. If a message has not been properly heard, "Say again" will be transmitted so that the message will be repeated, and confirmed by using "I say again".

18) To establish a clear transmission, the verb read will be used instead of hear or listen, and the indication of the signal strength will serve to identify the clarity of transmission. For example, to the question "How do you read me?", an answer will be "I read you fair with signal strength three" to signify that the signal received is "fairly good".

19) In the case of corrections and repetitions, the words correction and repeat will be used respectively to correct a mistake or repeat a part of a message of sufficient importance for the situation given. For example, "My last port of call was Algeciras, repeat, Algeciras" (A1/6.1.1.7.1)

20) Relevant data concerning ship's position, course, bearing or speed, as well as relevant data concerning the navigation itself (such as geographical names, time or distance) will comply with specific requirements. For instance, distances will be expressed in nautical miles or cables (tenths of a mile) and the unit will be stated; speed will be expressed in knots; or times will be expressed in the 24-hour UTC notation unless "local time" is clearly stated. For example: "Ice-breaker assistance will be resumed at one-two-one-five hours UTC" (A1/5.2.1.3).

21) Modal verbs may, might, should, could and have to are to be avoided with preference to message markers or other options such as "You have permission to ..." instead of "you may ..." or "you can ...", or "Advice. Correct the list of the vessel" (A1/4.2.13) will be used instead of "You should correct the list of the vessel". Must and need not will be used to express obligation (or instruction) and absence of obligation, respectively. Example: "Yes, you must take two tugs" (A1/4.3.1.1) and "No, you need 
not take two tugs" (A1/4.3.1.2). As regards modal can, it will be used to express capability rather than possibility. Example: "I cannot locate you on my radar screen" (A1/6.2.2.1.8).

General compilation features $2,3,4,7,8$, and 9 might also be regarded as specific in that they signal actual language use and are to be applied to any messages transmitted and language not explicitly contained in the SMCP.

\subsection{Move and discursive feature analysis of verbal messages}

Making use of the move-step model detailed in subsection 3.2. and the list of general and specific discursive features in subsection 3.3., I will try to show how vessels communicate with each other or with coastal stations. With this purpose in mind two examples of different kinds are included and labelled with reference to explanations provided in the two previous subsections, that is, moves, steps and discursive features (labelled as DF).

Example 1 illustrates a typical special-purpose message. The message text has been extracted from Van Kluijven (2003: 14). Here, a ship named MV Garland is having problems with her main engine, is not manoeuvring easily and needs to be towed. She advises all ships in the area to keep clear of her way.

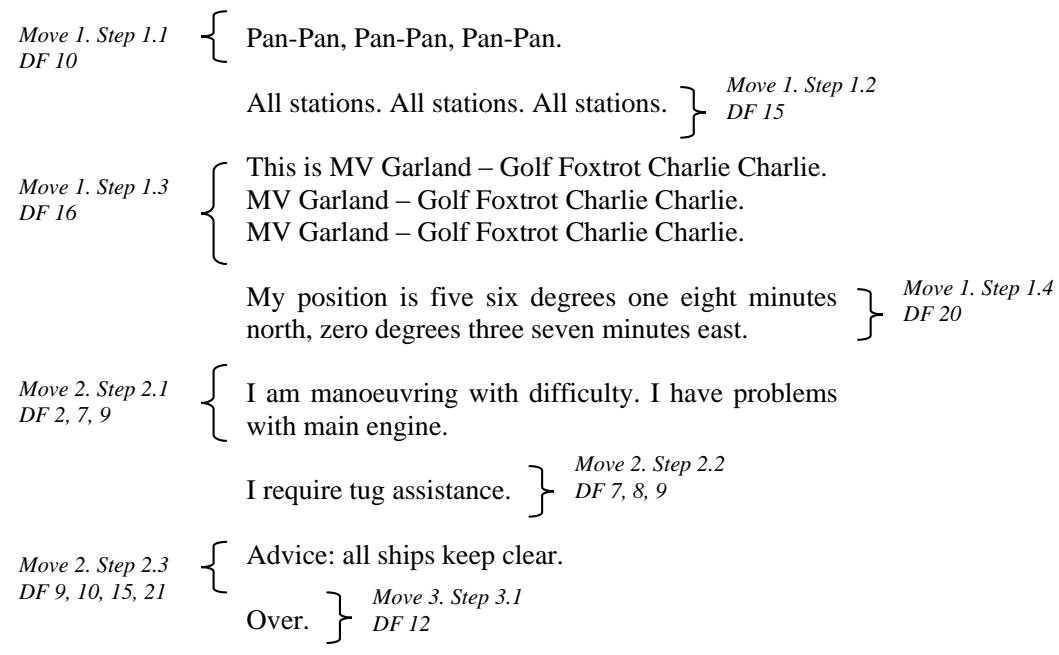

Example 1: Moves, steps and discursive features in a special-purpose message.

In this example, $M V$ Garland is transmitting an urgent message to all potential receiving stations and ships in the vicinity. The three moves together with their eight steps (see Table 2) are fully accomplished. Four general discursive features (numbers 2, 7, 8, and 9) and six specific discursive features (numbers 10, 12, 15, 16, 20, and 21) apply. 
VHF STATION A:

Gammon, Golf Xray Xray Xray.

Gammon, Golf Xray Xray Xray.

Move 1 Step 1.1 DF 15

This is Stowbridge Port, Stowbridge Port.

On VHF channel one-six.

Over.

Move 1 Step 1.1 DF 15

Move 1 Step 1.2 DF 16

Move I Step 1.3 DF 9, 14

VHF STATION B:

Stowbridge Port

This is Gammon.

Over.

Move 1 Step 1.4 DF 12

Move 1 Step 1.1 DF 15

Move 1 Step 1.2 DF 16

Move 1 Step 1.4 DF 12

\section{VHF STATION A:}

Gammon.

This is Stowbridge Port.

Switch to VHF channel one-four.

Over.

Move 1 Step 1.1 DF 15

Move 1 Step 1.2 DF 16

Move 1 Step 1.3 DF 9, 14, 21

Move 1 Step 1.4 DF 12

\section{VHF STATION B:}

Stowbridge Port

This is Gammon.

Move 1 Step 1.1 DF 15

Move 1 Step 1.2 DF 16

Move 1 Step 1.3 DF 9, 14

Agree VHF channel one-four.

Over.

Move 1 Step 1.4 DF 12

\section{VHF STATION A:}

Gammon.

This is Stowbridge Port

INFORMATION: Dredging operations

completed in South fairway.

Over.

Move 2 Step 2.1.a. DF 15

Move 2 Step 2.2.a. DF 16

Move 2 Step 2.5.a. DF 7, 8, 9, 10

Move 2 Step 2.6.a. DF 12

\section{VHF STATION B:}

Stowbridge Port.

This is Gammon.

Say again.

Over.

Move 2 Step 2.1.a. DF 15

Move 2 Step 2.2.a. DF 16

Move 2 Step 2.5.a. DF 17

Move 2 Step 2.6.a. DF 12

\section{VHF STATION A:}

Gammon.

This is Stowbridge Port.

I say again.

INFORMATION: Dredging operations

completed in South fairway.

Over.

Move 2 Step 2.I.b. DF 15

Move 2 Step 2.2.b. DF 16

Move 2 Step 2.3.b. DF 17

Move 2 Step 2.3.b. DF 7, 8, 9, 10

Move 2 Step 2.4.b. DF 12

\section{VHF STATION B:}

Stowbridge Port.

This is Gammon.

INFORMATION RECEIVED: Dredging operations completed in South fairway.

Thank you.

Nothing more.

Over.

Move 3 Step 3.1 DF 15

Move 3 Step 3.2 DF 16

Move 3 Step 3.3 DF 7, 8, 9, 10

Move 3 Step 3.4 DF 13

Move 3 Step 3.5 DF 13

Move 3 Step 3.6 DF 12

\section{VHF STATION A:}

Gammon.

Move 3 Step $3.1 \mathrm{DF} 15$

This is Stowbridge Port.

Out.

Example 2: Moves, steps and discursive features in a routine message. 
Example 2 above, extracted from Weeks et al. (1988: 86-87), illustrates a routine message. In this typical exchange procedure, VHF Station A is Stowbridge Port, a shorebased station; and VHF Station B is a ship named Gammon. Here, the shore-based station notifies vessel Gammon that dredging operations have been completed in the area she is approaching or navigating. This is the target issue of the communicative exchange that serves to illustrate Move 2. The cyclical nature of routine messages is shown in both Move 1 (with the need to agree on the VHF working channel) and Move 2 (with the repetition and acknowledgement of information). Except for steps 2.3.a. and 2.4.a., this conversation helps to illustrate the three moves and sixteen steps involved in a routine call (see Table 3). Regarding discursive features, numbers 7, 8, and 9 (general) and numbers 10, 12, 13, 14, 15, 16,17 , and 21 (specific) apply throughout the three moves making up the complete message.

\section{CONCLUSION}

In this paper I have examined the position of Maritime English within the shipping industry and for seafaring purposes so as to raise awareness on this particular English for Specific Purposes branch. However, my main concern has been to show and discuss how verbal messages are constructed and delivered at sea. With this aim I have paid particular attention to the main features of standardized speech communications by first classifying radiotelephony calls into two main types of messages and then explaining the informative function of message markers for ensuring effective communication. Following this, I have resorted to Swales's (1981) moves and steps to outline the communicative stages governing spoken standard Maritime English. The resulting model provides the move and step structure governing special-purpose and routine communicative exchanges between ships and between ships and shore-based facilities. This, together with the analysis of the general and specific discursive features of standardized verbal messages as recommended by IMO and other organizations, have been applied to two examples in an effort to illustrate the standardized language previously detailed and discussed, prove the relevance and adequacy of the movestep model for the study of marine communications, and contribute to the understanding of how speech communications at sea are structured and developed.

Regarding English for marine communications, there is still much to be done in the area of analyzing standardized language use at the workplace; in this particular case, ships and shore facilities such as coastal stations or vessel traffic services. How and to what extent standard communication procedures at sea and actual practice differ, given the existence of inconsistencies pointed out in the relevant literature, are issues which remain underresearched. However, the technical complexity of eliciting real instances of language use in a marine environment (human interactions both aboard ship and at shore-based stations) and the difficulty in having access to workplace data (given the restrictions of data protection measures) pose a real challenge to researchers worldwide. 


\section{NOTES}

${ }^{1}$ For a discussion on the role of IMO in the standardization of the English language as used at sea, see Bocanegra Valle and De la Campa (2006), and Bocanegra-Valle (2010).

${ }^{2}$ Among these textbooks, Weeks et al.'s (1988) Seaspeak, developed as a result of the cooperation between master mariners and applied linguists is the most renowned and "probably the best manual on marine communications published to date" (Díaz Pérez, 2002: 654).

${ }^{3}$ For illustrating examples in which English language problems in communicative events have contributed to real shipping accidents, see Kahveci and Sampson (2001), Squire (2006), or BocanegraValle (2010), among others.

${ }^{4}$ Díaz Pérez (2005) reports that the real first attempt in supporting the English language as the language of the sea was in 1973, when a limited group of basic phrases known as "Safety phrases" were developed for use by ships or crews in distress. For a detailed analysis of the SMNV see Bocanegra Valle (1999) and Díaz Pérez (2005).

${ }^{5}$ For a detailed explanation of Maritime English as a part of the human factor dimension, see Bocanegra-Valle (2010).

${ }^{6}$ Thanks to these preformatted automatically-transmitted messages, rescue coordination centres will, among others, receive accurate information concerning the ship's location immediately after a distress occurs (thus, speeding up search and rescue operations).

${ }^{7}$ Figures in brackets following the examples provided refer to the chapter and phrase number in the SMCP (IMO, 2001).

${ }^{8}$ Tildes $(\sim)$ indicate alternative complementary phrases for the preceding standard phrase.

9 The Phonetic Alphabet and The Figure Code may be found at URL: http://www.alphabravocharlie.info/alphabet.php.

${ }^{10}$ MMSI stands for Maritime Mobile Service Identity and the MMSI code is a 9-digit code which allows for the ready identification of a vessel. Call signs are a combination of letters, unique to each transmitting station, to be spoken using the Phonetic Alphabet.

\section{REFERENCES}

Blakey, T.N. (1987). English for Maritime Studies. London: Prentice-Hall.

Bocanegra Valle, A. (1999). La normalización de la lengua inglesa para fines específicos: el caso de las comunicaciones marítimas. In S. Barrueco, E. Hernández \& L. Sierra (Eds.), Lenguas para Fines Específicos (VI) Investigación y Enseñanza (pp. 477-483). Alcalá de Henares: Universidad de Alcalá de Henares.

Bocanegra-Valle, A. (2010). Global markets, global challenges: the position of Maritime English in today's shipping industry. In A. Linde López \& R. Crespo Jiménez (Eds.), Professional English in the European Context: The EHEA Challenge (pp. 151-174). Berlin: Peter Lang.

Bocanegra Valle, A. \& De la Campa Portela, R.M. (2006). El papel normalizador de la OMI en el conocimiento, uso y aprendizaje de la lengua inglesa como lengua internacional del mar. In M.C. Pérez-Llantada Auría, R. Plo Alastrué \& C.P. Neumann (Eds.), Proceedings of the 5th International AELFE Conference (pp. 420-424). Zaragoza: Prensas Universitarias de Zaragoza.

De la Campa, R.M. (2003). Communication breakdown. Marine Engineers Review, Dec/Jan 2003, 3435.

De la Campa, R.M. (2007). Particularidades de las radiocomunicaciones marítimas. In R.M. De la Campa (Ed.), Traducción automática del habla aplicada a las comunicaciones en el ámbito marítimo (pp. 29-50). A Coruña: Universidad de A Coruña.

De la Campa Portela, R.M., Louzán Lago, R.M. \& Fernández Hermida, S. (2007). Estudio sobre el uso real de las frases normalizadas de la OMI en las comunicaciones marítimas. In R.M. De la 
Campa (Ed.), Traducción automática del habla aplicada a las comunicaciones en el ámbito marítimo (pp. 141-151). A Coruña: Universidad de A Coruña.

Díaz Pérez, J.M. (2002). IMO Standard Marine Communication Phrases and teaching their use in the Vessel Traffic Services context. In Proceedings of the 3rd International Congress on Maritime Innovations and Research (pp. 649-658). Bilbao: Universidad del País Vasco.

Díaz Pérez, J.M. (2005). Inglés náutico normalizado. Barcelona: MARGE Books.

IMO (1977). Standard Marine Navigational Vocabulary. Resolution A.380 (X), 14 November 1977. London: International Maritime Organization.

IMO (2001). Standard Marine Communication Phrases. Resolution A.918(22), 29 November 2001. London: International Maritime Organization.

Johnson, B. (1995). Some features of maritime telex service communication. English for Specific Purposes, 14(2), 127-136.

Johnson, B. (1999). English in the Global Maritime Distress and Safety System. World Englishes, $18(2), 145-157$.

Kahveci, E. \& Sampson, H. (2001). Findings from the shipboard based study of mixed nationality crews. In Proceedings of SIRC's Second Symposium (pp. 39-60). Cardiff: Cardiff University, Seafarers's Research Centre.

MAIB (2000). Case 5 Misunderstanding leads to a near miss in port approach channel. In Marine Accident Investigation Branch (MAIB) - Safety Digest 01/00 (pp. 14-15). Retrieved from http://www.maib.gov.uk/cms_resources.cfm?file=/SD_1_2000.pdf

Olaru, I. (1996). The style of the seafaring language, the definite communicative aim of maritime language. The IMLA Newsletter, 22, 17-23.

Pritchard, B. (1999). Maritime English. Udine: Del Bianco Editore.

Pritchard, B. (2000). Maritime VHF communications: standards versus practice. In Proceedings of the 2nd IMLA Workshop on Maritime English in Asia (pp. 44-54). Dalian: Dalian Maritime University.

Pritchard, B. (2003a). Maritime English syllabus for the modern seafarer: safety-related or comprehensive courses? WMU Journal of Maritime Affairs, 2(2), 149-166.

Pritchard, B. (2003b). Maritime Communications and IMO SMCP 2001 (draft version). Retrieved from http://www.pfri.uniri.hr/ bopri/documents/MaritimeCommunicationsandSMCP_001.pdf

Pritchard, B. \& Kalogjera, D. (2000). On some features of conversation in maritime VHF communication. In M. Coulthard, J. Cotterill \& F. Rock, F. (Eds.), Dialogue Analysis VII: Working with Dialogue (pp. 185-196). Tübingen: Max Niemeyer Verlag.

Short, V.A. (2006). Maritime English. Valuing a common language. Seaways, the Journal of the Nautical Institute, supplement to October 2006, 1-12.

Squire, D. (2006). The human element. The importance of effective communication. A presentation to the Maritime Communications \& Technology Conference, London. Retrieved from http://www.he-alert.com/documents/published/he00615.pdf

Swales, J.M. (1981). Aspects of Article Introductions. Birmingham: University of Aston.

Trenkner, P. (2000). Maritime English. An attempt of an imperfect definition. In Proceedings of the 2nd IMLA Workshop on Maritime English in Asia (pp. 1-8). Dalian: Dalian Maritime University.

Trenkner, P. (2005). The IMO Standard Marine Communication Phrases - Refreshing memories to refresh motivation. In Proceedings of the IMLA $17^{\text {th }}$ International Maritime English Conference (pp. 1-17). France: Marseille.

Van Kluijven, P.C. (2003). The International Maritime Language Programme. Alkmaar: Alk \& Heijnen Publishers.

Weeks, F.F. (1986). Wavelength. Madrid: Alhambra.

Weeks, F.F., Glover, A., Johnson, E. \& Strevens, P. (1988). SEASPEAK Training Manual. Oxford: Pergamon. 